\title{
Measures of statistical dispersion based on Entropy and Fisher information
}

\author{
Lubomir Kostal", Petr Lansky, Ondrej Pokora \\ From Twentieth Annual Computational Neuroscience Meeting: CNS*2011 \\ Stockholm, Sweden. 23-28 July 2011
}

\begin{abstract}
We propose and discuss two information-based measures of statistical dispersion suitable to description of interspike interval data. The measures are compared with the standard deviation. Although the standard deviation is used routinely, we show that it is not well suited to quantify some aspects of dispersion which are often expected intuitively, such as the degree of randomness. The proposed dispersion measures are not mutually independent, however, each describes the firing regularity from a different point of view. We discuss relationships between the measures and describe their extreme values. We also apply the method to real experimental data from spontaneously active olfactory neurons of rats. Our results and conclusions are applicable to a wide range of situations where the distribution of a continuous positive random variable is of interest.
\end{abstract}

\section{Acknowledgements \\ This work was supported by AV0Z50110509 and Centre for Neuroscience LC554.}

Published: 18 July 2011

\section{References}

1. Kostal L, Lansky P, Rospars JP: Review: Neuronal coding and spiking randomness. Eur J Neurosci 2007, 26:2693-2701.

2. Kostal L, Marsalek P: Neuronal jitter: can we measure the spike timing dispersion differently? Chin J Physiol 2010, 53:454-464.

Submit your next manuscript to BioMed Central and take full advantage of:

- Convenient online submission

- Thorough peer review

- No space constraints or color figure charges

- Immediate publication on acceptance

- Inclusion in PubMed, CAS, Scopus and Google Scholar

- Research which is freely available for redistribution

Submit your manuscript at www.biomedcentral.com/submit 